\title{
LEAVES OF GRASSROOTS POLITICS: WHITMAN, CARLYLE, AND THE IMAGINATION OF DEMOCRATIC VISTAS
}

\author{
SCOTt HeNkel
}

"Democracy," Walt Whitman writes, "is a word the real gist of which still sleeps, quite unawaken'd, notwithstanding the resonance and the many angry tempests out of which its syllables have come, from pen or tongue. It is a great word, whose history, I suppose, remains unwritten, because that history has yet to be enacted." 1 This claim appears in Whitman's 1871 essay Democratic Vistas, and as the metaphor of the title makes clear, Whitman uses his text to look ahead, to imagine an idea of democracy to come. Whitman signals to us that such work is historical in nature: theorizing possible futures necessitates an understanding of our past. As Manning Marable writes, "[h] istorical amnesia blocks the construction of potentially successful social movements. . . . Thus, for the oppressed, the act of reconstructing history is inextricably linked to the political practices, or praxis, of transforming the present and future." ${ }^{2}$ Few texts are more important than Democratic Vistas in debates about literary history's value for prefiguring possible democratic futures, but how are we to use our literary history for contemporary politics?

Roberto Mangabeira Unger and Cornel West call Democratic Vistas "the secular bible of democracy" 3 and Stephen John Mack has recently called the text Whitman's "most profound and sustained meditation on democratic life." "Like Unger, West, and Mack, I believe that Democratic Vistas is still capable of helping us address our contemporary political problems. Whitman wrote his text, in part, as a rebuttal to Thomas Carlyle's essay "Shooting Niagara: And After?" 5 Whitman directly responds to Carlyle's criticism of democracy, naming him at several moments in the text, and, in doing so, Whitman positions Carlyle as the counterpoint to his own position. Carlyle's essay is shockingly bigoted, and this fact may have caused scholars to reject his ideas largely without scrutiny. Carlyle's ideas are offensive, but they are not locked safely in the past. Quite the contrary, the ideas that animated both Carlyle and Whitman still inform contemporary debates about democracy. Much of the scholarship on Democratic Vistas has given the conversation between Carlyle and Whitman only a brief treatment and has, there- 
fore, not sufficiently unpacked what Whitman thought was the task of "advanced students" and people "of any brains": to argue for "a wider democratizing of institutions" and to think about "how, and in what degree and part, most prudently to democratize" ( $P W, 2: 382-383$ ). This debate largely focuses on two competing values - authority and autonomy - and the degree to which these values undercut or undergird our ideas about democracy. As I will show, the dynamics of the debate between Carlyle and Whitman can be instructive for those of us who believe that the intersection of literary study and the study of political movements is vital to a thriving democratic culture.

But how we use this history is a matter of crucial concern. In The Pragmatic Whitman: Reimagining American Democracy, Mack suggests that Whitman's ideas are usefully viewed though the pragmatist's lens. After demonstrating the ways that Whitman's thinking fits the pragmatic tradition, he seeks to "explore Whitman's mature vision in Democratic Vistas and conclude with some observations on its moral and political implications for contemporary America" (xix). Mack seeks, in other words, to look through Whitman's eyes and to speculate about what he might have said about contemporary politics if he were transported from the nineteenth century into the twenty-first. Mack pays careful attention to the historical circumstances in which Whitman's ideas were formed, and this is to his credit. But the lessons of Democratic Vistas have little to teach us if we hope to impose Whitman's vision upon ourselves. Instead, we ought to stand upon Whitman's shoulders and take stock of what we can see from that new vantage point.

To a significant degree, our contemporary debates about democratization continue to revolve around the problems of authority and autonomy, as they did for Carlyle and Whitman. Although they arrive at different conclusions, Carlyle and Whitman agree that the degree to which common people - whom Carlyle calls "the swarm" ("SN," 4) and Whitman calls "the unnamed, unknown rank and file" (PW, 2:377) have the capacity for autonomy is the same degree to which democracy is viable. Carlyle lamented the fact that the political movements of his day were "cutting asunder [the] straps and ties . . . of old regulations, fetters, and restrictions" because he sees no capacity for autonomy in the swarm ("SN," 9). Instead, he hopes for an enlightened leadership class to govern us and to direct our affairs - the class of people whom he calls "heroes" in "Shooting Niagara" ("SN," 33-34) and, more fully, in his book On Heroes, Hero-Worship, and the Heroic in History. ${ }^{6}$ Whitman writes that the "purpose of democracy" is to cultivate the "highest freedom" so that "the unnamed, unknown rank and file" can "become a law, and a series of laws, unto" themselves ( $P W, 2: 374-375)$. Additionally, Whitman knows that autonomy in a democracy is not about atomistic individuals, but rather it is always a negotiation between "a 
large variety of character" and "full play for human nature to expand itself in numberless and even conflicting directions" ( $P W, 2: 362)$, or, in other words, the problem of continually expanding our ideas and practices of freedom while simultaneously living peacefully with others.

In the debate between Carlyle and Whitman in the pages of "Shooting Niagara" and Democratic Vistas, we can find no less than a broad conversation about the theoretical scaffolding, and therefore the viability, of democracy itself. While I am reminded of what Kenneth M. Price calls Whitman's "signature expression"- "Be radical—be radical—be not too damned radical!" 7 - I will argue that we can find in Democratic Vistas the seeds of a political project that I will call grassroots politics: Whitman's proposal for the democratization of "all public and private life" (PW, 2:389). This argument differs from that which we find in The Pragmatic Whitman in two key ways: first, I see far more radical ideas and potential in Democratic Vistas, and second, the technique that I will use will situate Whitman in his historical moment and indicate the debate's implications for contemporary politics. Whitman believed that America in the nineteenth century needed a new conception of democracy to differentiate it from Carlyle's "old order"; likewise, we need a twenty-first-century interpretation of democracy. The debate between Carlyle and Whitman provides an opportunity to frame just such a project.

My goals for this essay are to explicate the debate between Carlyle and Whitman to a greater degree than has yet been attempted in the scholarship, and to refocus this debate in a way that I believe will be a valuable contribution to grassroots political movements. When I use the phrase grassroots politics, I do not define it as a synonym for populism, as it is normally used in popular and scholarly texts. I use it in the more radical sense that comes from my reading of Democratic Vistas: radicalism and grassroots politics suggest getting to the roots-a more direct democracy, one that is less mediated through representatives like Carlyle's heroes, and is, therefore, more meaningful to more people. This interpretation stems from the emphasis Whitman places on the autonomy of "the unknown, unnamed rank and file" (PW, 2:377), who, in Whitman's mind and my own, ought to see democracy as a way to "become a law, and series of laws" unto themselves (PW, 2:375). I also couple my understanding of grassroots politics with Whitman's emphasis on the negotiation between expanding our ideas and practices of freedom while living peacefully with others. This implies a focus on democratic political movements - swarmery in the best sense-that provide ways for the demos, people, to become a kratos, force. To accomplish the essay's goals, I will first comment on the aspects of The Pragmatic Whitman that need to be called into question. Next, I will reframe the debate between Carlyle and Whitman, and finally, I will 
recast the debate in ways that will help us to look a bit further into the democratic vistas.

\section{Whitman's "Imposition"}

As his title suggests, Mack attempts to marshal Whitman into the pragmatic tradition, writing that "[o]ne of [his] intentions in this study is to demonstrate, more thoroughly than other authors have previously tried, how Whitman participates in [the pragmatic] tradition and how the insights of other pragmatist thinkers can help to produce worthwhile readings of his poetry and, by extension, his democratic poetics" (xix). Mack wants to claim Whitman for the pragmatic tradition, and he finds copious evidence.

Other writers have made similar moves. Michel Fabre points out that Emma Goldman and Eugene Debs, for example, admired Democratic Vistas and Leaves of Grass and, to varying degrees, appropriated Whitman's ideas for their projects. ${ }^{8}$ In our historical moment, the metaphor of Whitman's essay has been appropriated by writers like George Will to put a bright façade on the atrocity of the current Iraq occupation. ${ }^{9}$ There is enough ambiguity in Whitman's writings to produce these divergent readings; therefore, I do not fault Mack for using the pragmatist's lens. I simply believe that Democratic Vistas, and, as Marable suggests, the political movements that could see it as part of a usable past, are better served by reading the text through a more radical lens.

My first objection to Mack's argument is that writers in the pragmatist tradition often place an undue emphasis on the problem of identifying and training the class of people who would make the best leaders - the problem, in other words, of a political vanguard. In this vein, Cornel West writes in The American Evasion of Philosophy: A Genealogy of Pragmatism that the "pragmatists' preoccupation with power, provocation, and personality - in contrast, say, to grounding knowledge, regulating instruction, and promoting tradition - signifies an intellectual calling to administer to a confused populace caught in the whirlwinds of societal crisis, the cross fires of ideological polemics, and the storms of class, racial, and gender conflicts." 10 But the pragmatic tradition also includes another view. Writing about a decade later, West tempers his position: in the paragraph in which he and Unger call Democratic Vistas the "secular bible of democracy," they write that the "fundamental strand in the American religion of possibility" is a "faith in the genius of ordinary men and women. . . . The capacity for strong and original experience, rather than being confined to a small number of geniuses, heroes, and eccentrics, should become widespread among ordinary people" (West \& Unger, 11). 
While Mack writes that "Whitman had always understood that democracy could only be justified by a faith that every human being possessed a natural capacity for self-governance" (137), The Pragmatic Whitman places a greater emphasis on the role of visionary leadership. To orient his reading of Democratic Vistas, Mack quotes Erik Erikson's Childhood and Society: "political, economic, and technical elites, whenever they have accepted the obligation to perfect a new style of living at a logical point in history, have provided men with a high sense of identity and have inspired them to reach new levels of civilization" (133). Mack writes that Whitman's remedy to political problems does not call for a "bureaucracy of experts" (151) to administer for the rest of us, but the question is not about a bureaucracy. Mack's argument is founded on the problem of living up to the ideas that visionary leaders provide for us. This is not to say that autonomy is unimportant to the pragmatists, but rather to say that, in the pragmatist tradition, one has a choice to place an emphasis on Cornel West's earlier comments about "administer[ing] to a confused populace" or on West and Unger's later comments about "faith in the genius of ordinary men and women." Mack chooses the former.

It is this assumption about fidelity to inspired visionaries that leads Mack to use Whitman in the ways he does-as someone who presents an "imposition" to be obeyed. Accordingly, Mack argues that the "importance of Whitman's democracy . . . is to be found in the moral quality of whatever demands it makes upon those who take its principles to heart. . . . To understand the moral and political demands that Whitman's vision entails we need to look to the forces that shaped its growth" (xxi). Understanding the context out of which Whitman's political ideas developed is a valuable scholarly activity. However, to take those ideas, shaped as they were by the politics of the nineteenth century, and to apply them to the politics of the twenty-first century is a mistake. Political challenges may retain their broad themes in different historical moments; important values like authority and autonomy may, at first glance, seem universal because concerns about them endure. But to suggest that these problems are exactly the same, or to suggest that political praxis could transcend history is, in Whitman's own words, to use Democratic Vistas as "fossil theology" (PW, 2:409).

In the last two sentences of The Pragmatic Whitman, Mack writes that Whitman's “challenge to us is to identify-and reconcile- the real, historically specific content of these competing definitions of liberty. To accept that challenge is to continuously restructure the terms of associative life in ways that secure ever-newer forms of freedom" (165). However, this historical specificity is not used in Mack's technique 
for commenting on contemporary politics. Instead, Mack urges us to think with Whitman's mind, to follow his vision and to accept the consequences that such a vision imposes upon us.

Mack writes that "Democratic Vistas is a blueprint for a kind of literary criticism designed to promote social change" (142). To follow this blueprint, Mack helps us to see what he calls "Whitman's vision":

The idea of individual freedom did not die as a political ideal, supplanted by notions of the regulated state. To be sure, both live on as the great antinomies of the American democratic tradition. The particular virtue of Whitman's vision is that it strives to bring these philosophical antagonists into relation.... As Whitman sees it, all public debate in a democratic society is necessarily structured by the opposing ideals of liberty and governance. (xxii)

Mack concludes his book by interpreting the "particular virtue of Whitman's vision" and using that interpretation to comment on current issues in American politics. This move is a version of presentism in reverse: rather than viewing the nineteenth century through the eyes of the twenty-first, as some people mistakenly do, Mack makes the equal and opposite mistake when he interprets what he believes Whitman's vision to be and "conclude[s] with some observations on its moral and political implications for contemporary America" (xix). Mack's strategy is to import Whitman's ideas, altered by interpretation, but not historical specificity, into the present.

"To understand the scope of the demands that Whitman's vision imposes on us," Mack writes, "we should begin by recalling that democracy, for Whitman, is more than the political process" (160, emphasis mine). The last part of Mack's comment is correct: Whitman does clearly argue that democracy is not just "for elections, for politics, and for a party name" (PW, 2:389). The first part of Mack's assertion is problematic, however: why must "Whitman's vision" be "impos[ed]" upon us? While we may have a debt to pay to Whitman, this debt does not mean that we ought to think with his mind - to do so would take away our right to make political decisions based on our own circumstances, and it would be to accept the limitations of Whitman's vision as well. My criticism, simply expressed, is that Whitman's own politics are historically situated, as are ours. While the problems Whitman faced are antecedents to our own, and therefore similar in many ways, it would be a mistake to assume that the lessons we take from Democratic Vistas need not be situated in our own historical moment if we hope to apply those lessons to our contemporary political situation. The argument is not whether our literary history has something to offer contemporary politics-it certainly does-but rather about the best way to use this history. 
On this point, Robert Leigh Davis is exactly correct: "Democratic Vistas begins with a view of authors as legislating gods hardwiring the political unconscious of the nation. It ends with a view of readers challenging those gods, wrestling with them, and in that democratic gymnasium finding the true measure of their strength." 11 We find no such challenge to the gods in The Pragmatic Whitman, and this becomes apparent when Mack begins to apply Whitman's vision to specific areas of contemporary public policy:

Whitman's organic democracy does . . . place complex demands on the ways we attempt to fashion a meaningful associative life. To cite just one example, consider its implications for the way we approach the problem of economic privation and the distribution of wealth. . . . Paternalistic and dehumanizing policies such as welfare are, however nobly intentioned, almost as odious as official indifference. Just as it would be absurd for a society to offer the ballot as a substitute for food, so, too, would it be unthinkable to design a policy that assists the poor by crippling their capacity for engaged democratic living-by dismantling the psychological equipment a citizen needs for self-government while simultaneously undermining the high value democratic culture places on self-reliance. (163-164)

Because welfare programs are beyond Whitman's nineteenth-century vision, they ought to be beyond ours as well, Mack argues. Even though Mack refers at one point to "the shackles of a laissez-faire democratic theory" (99), the comments about the distribution of wealth leads one to believe that Mack advocates a return to the laissez-faire policies of the nineteenth century. The main characteristics of this interpretation seem to be the importance of bootstrap-style self-reliance and the absence of "paternalistic and dehumanizing policies such as welfare" (164). To accept Whitman's vision, it seems, is to tear holes in the social safety net. If we were to choose to do so, we could point out that Mack fails to see the value that Whitman placed on equality $(P W, 2: 396)$ and the "great word Solidarity" ( $P W, 2: 382)$, which would mitigate the claims that Mack makes. But these speculations are answers to the wrong questions. Rather than imposing Whitman's ideas upon the present, we might use Democratic Vistas as a touchstone to reformulate the questions of democratization for our historical moment and then see what our answers might provoke.

The reasons for not wanting to impose Whitman's vision upon our historical moment could not be clearer. Ed Folsom and others have shown conclusively that while Whitman had many admirable political ideas, even the most advanced would seem regressive to us. ${ }^{12} \mathrm{~A}$ sympathetic reader may look at Whitman's nascent multiculturalism and praise him for the parts of his thinking that were, at many moments, more advanced than his peers. In our time, however, Whitman's stances 
on racial equality, gender equality, and class equality are clearly regressive. Whitman's tepid response to the racism of "Shooting Niagara," for example, lays bare the fact that Whitman is not willing to respond to Carlyle on this point in fully-throated ways. For Carlyle, questions of citizenship and equality along racial lines were merely frivolous. As Folsom notes, Whitman does not adequately challenge Carlyle's racism because, for "Whitman, as for many white Americans in the Civil War era, it was possible to be opposed to slavery but also to be against equal rights for African Americans" (46). Who among us, except for rabid fringe, would take such a position today? When Whitman displays nascent multicultural or feminist leanings, for example, they are impressive precisely because of his position in the nineteenth century-a moment when aspects of his vision were well beyond many of his peers. Today, his vision would be viewed as an anachronism.

Furthermore, so many elements of our politics are beyond Whitman's vision. To take just one example, Whitman could not imagine a scenario where corporate power rivals or exceeds government power, as it does today. The roots of this problem are found in the nineteenth century: it was the Supreme Court's Santa Clara decision in 1886 that codified the idea that corporations have the same rights as people. ${ }^{13}$ Whitman saw that the legacy of reconstruction was being bastardized for all sorts of nefarious purposes, as in Santa Clara. But to expect Whitman's nineteenth-century vision of capitalism to be able to explain the corporate threats to democracy today is to stretch an historical analysis of Whitman's own vision beyond the breaking point. ${ }^{14}$ The degree to which Democratic Vistas is valuable for grassroots politics is the same degree to which we are able to cease using Whitman's vision as a blueprint to be imposed and begin to use his ideas as historical touchstones.

Rather than reading Whitman in the hope of discovering what he might think about our contemporary politics, the alternative is to explicate the texts in ways that are historically situated in both Whitman's moment and our own. I would argue that this method holds truer to the ideals that Whitman himself expressed: to honor Whitman's style is to learn "under it to destroy the teacher," to take Whitman's ideas and to advance them in ways that are beyond his own historical vision. ${ }^{15}$ The problems Whitman faced are historical antecedents to our own, but we need to ask new questions and also therefore arrive at different answers to what Whitman calls "the great question of democracy" (PW, 2:363).

On this point, we can take clues from David Scott's work in Conscripts of Modernity: The Tragedy of Colonial Enlightenment. Scott writes that his "most general concern . . . is with the conceptual problem of political presents and with how reconstructed pasts and anticipated futures are thought out in relation to them."16 In many ways, Scott's 
method is reminiscent of Whitman's own orientation in Democratic Vistas - certainly the task of prefiguring the future requires an understanding of our past. But Scott introduces an idea that diverges from Whitman as well. He writes that his aim is

to make out a case for a practice of criticism that is alert to the idea that propositions are always answers to questions or interventions in a discursive context, because it seems to me that keeping this idea in view is one way of helping us to determine whether the questions we have been asking the past to answer continue to be questions worth having answers to, and whether the stories we have been telling ourselves about the past's relation to the present continue to be stories worth telling. (209)

In Scott's method, political movements are always best understood as historical in nature, but the problem he sees is that it is insufficient to continue to ask the same questions that previous thinkers did, only to arrive at new answers. Scott argues that the best way to approach the history of these movements, and to construct possible futures from that history, is also to ask new questions about the movement's history and possible futures, and also, therefore, to arrive at new answers to those questions. In this vein, we can revisit the debate between Carlyle and Whitman, and reassess not only the answers that Whitman gives to political problems, but also the questions that he asks.

\section{Shooing the Swarm}

Whitman was fairly frequently concerned with Carlyle's writing, and as Davis points out, he owed Carlyle both an intellectual and an artistic debt (541). Whitman wrote in his Brooklyn Daily Eagle review of On Heroes, Hero-Worship, and the Heroic in History that Carlyle is a "Democrat" in an "enlarged sense," meaning that "he is quick to champion the downtrodden, and earnest in his wrath at tyranny." 17 But by the time Specimen Days was published, Whitman's views on Carlyle were much different. In the essay "Carlyle from American Points of View," for example, Whitman writes that "Carlyle's grim fate was cast to live and dwell in, and largely embody, the parturition agony and qualms of the old order, amid crowded accumulations of ghastly morbidity, giving birth to the new" ( $P W, 1: 254)$. Whitman recognized in Carlyle something quite useful: a voice for this "old order," an order against which Whitman could imagine a more democratic future.

According to Thomas F. Haddox, "[a]lthough specifically a response to [Benjamin] Disraeli's Reform Bill, which was about to enfranchise much of the working class in Britain, 'Shooting Niagara' is more generally a condemnation of democratic government as such."18 Haddox is correct, but although Carlyle was critical of democracy, to 
be sure, his greater interest - and object of greater scorn-was what he called "the swarm": those people and political movements who were "cutting asunder [the] straps and ties . . . of old regulations, fetters, and restrictions" ("SN," 9). In Carlyle's mind, further democratization would not be wise: he argued that once allowed to rule itself, a task he sarcastically called "improvement," the "swarm" was "likely to be 'improved off the face of the earth' in a generation or two" ("SN," 7-8). For Carlyle, to take the "Niagara leap of completed Democracy" is to tempt fate in foolish ways ("SN," 3). Too much, too soon, for too many, Carlyle believes, is like the Niagara plunge: one chooses to take it, but it rarely has good results.

Whitman addresses this critique directly, and although he admits that his "mood" had been much like Carlyle's $(P W, 2: 375)$, it is " $[\mathrm{t}] \mathrm{o}$ him or her within whose thought rages the battle, advancing, retreating, between democracy's convictions, aspirations, and the people's crudeness, vice, caprices, I mainly write this essay" (PW, 2:363). Whitman writes that

Anything worthy to be call'd statesmanship in the Old World, I should say, among the advanced students, adepts, or men of any brains, does not debate to-day whether to hold on, attempting to lean back and monarchize, or to look forward and democratizebut how, and in what degree and part, most prudently to democratize. (PW, 2:383)

The friction between Carlyle and Whitman is about the meaning and scope of democracy: Carlyle's interpretation favors less democracymuch less; Whitman's favors more democracy-much more. Carlyle sees himself as grasping, trying to conserve an "old order" which he believes to be good and deserving; Whitman believes that such activity is an attempt to "lean back," a regression, an unwillingness to look into the democratic vistas. Whereas Carlyle mocks the idea that the democratic franchise should be extended to the "swarm," Whitman argues for "democracy in all public and private life, and in the army and the navy" (PW, 2:389).

Specifically, the friction between the authority of a leadership class and the autonomy of "the unnamed, unknown, rank and file" is important to Carlyle and Whitman because they reason that the metric used to determine if the people could rule in a democracy is the degree to which common people can rule themselves. Much depends on this facet of the debate: if one believes in what C. L. R. James calls "the creative power of freedom and the capacity of the ordinary man to govern" (par. 43), as Whitman does, then democracy itself rests on a sure foundation. ${ }^{19}$ The question for Carlyle was how to identify and train his class of heroes, and how to train the swarm to obey the heroes' vision. The question for Whitman was "how, and in what degree and 
part, most prudently" to prepare "the unnamed, unknown, rank and file" for democracy in "all public and private life"?

"Shooting Niagara . . . And After?" appeared anonymously in Macmillan's Magazine in April 1867, and was edited and expanded soon thereafter into a pamphlet. ${ }^{20}$ As James Anthony Froude writes, "Shooting Niagara"

was Carlyle's last public utterance on English politics. He thought but little of it, and was aware how useless it would prove. In [Carlyle's] Journal, August 3 [1867], he says:- "An article for Masson and Macmillan's Magazine took up a good deal of time. It came out mostly from accident, little by volition, and is very fierce, exaggerative, ragged, unkempt, and defective. Nevertheless I am secretly rather glad than otherwise that it is out, that the howling doggeries (dead ditto and other) should have my last word on their affairs and them, since it was to be had." 21

Carlyle knew that his "last word" would be met with strong resistance. The appeal for electoral reform at the time was widespread, with support from the Reform League and Reform Union, as well as the British labor movement. Subsequently, the British parliament passed the Reform Act of 1867, known as the Second Reform Act, mostly in an effort to appease the demands of the political movements. The Second Reform Act was intended to enfranchise sober, skilled men, and it had the effect of enfranchising much of the male working class. ${ }^{22}$

The argument of Carlyle's essay is rather straightforward: Carlyle mocks these efforts because he believes that the "swarm" does not have the capacity for autonomy that democracy requires. The "And After?" of his title speaks volumes: if the democratic franchise were to be expanded too widely, Carlyle argues, the nation as a whole would suffer. He begins his argument by resisting what was coming to be a foregone conclusion. Carlyle was waiting for

Democracy to complete itself; to go the full length of its course, towards the Bottomless or into it, no power now extant to prevent it or even considerably retard it, - till we have seen where it will lead us to, and whether there will then be any return possible, or none. Complete "liberty" to all persons; Count of Heads to be the Divine Court of Appeal on every question and interest of mankind; Count of Heads to choose a Parliament according to its own heart at last, and sit with Penny Newspapers zealously watching the same; said Parliament, so chosen and so watched, to do what trifle of legislating and administering may still be needed in such an England, with its hundred and fifty millions "free" more and more to follow each his own nose, by way of guide-post in this intricate world. ("SN," 1-2)

Why underscore "liberty" as Carlyle does? Why would Carlyle be so vocal in his skepticism of the "Penny Newspapers," those popular forces of commentary which would "watch" the Parliament? Carlyle evokes 
the anxiety of one who is about to be scrutinized in a certain way: by those members of the "swarm," those whom Carlyle feels are beneath this Parliament. Liberty to all persons, voting on issues, scrutiny of officials - these are democracy's faults in Carlyle's eyes. What Carlyle is describing are real threats to the political order: he sees an uncontrollable swarm jeopardizing the institutions of government and civil society. Carlyle correctly sees that these political movements may refigure the calculus of political power, and he reacts to conserve the order that he believes to be worth protecting.

In one of many interesting rhetorical constructions, Carlyle writes that "Count of Heads [will] be the Divine Court of Appeal on every question and interest of mankind; Count of Heads to choose a Parliament according to its own heart at last" ("SN," 1). Whereas a construction such as "the counting of heads . . ." would simply imply majoritarian rule, by writing "Count of Heads," capitalized and acting as the noun in his sentence, Carlyle is able to personify the electoral franchise with an aristocratic title. This particular personification illustrates Carlyle's conservative impulse: even the object of his critique is rendered in the language of the "old order."

A more ideal republic, Carlyle argues, would be hierarchically organized. Governing would be the sole purview of the educated and expert, who presumably have the most skill at the task, and who need not be "interfered with":

Supposing the Commonwealth established, and Democracy rampant, as in America, or in France by fits for 70 odd years past, - it is a favourable fact that our Aristocracy, in their essential height of position, and capability (or possibility) of doing good, are not at once likely to be interfered with; that they will be continued farther on their trial, and only the question somewhat more stringently put to them, "What are you good for, then? Show us, show us, or else disappear!" ("SN," 17)

Carlyle writes to defend hierarchical institutions like the "Aristocracy," which, in their "essential height of position," are jeopardized by democratization. Once democratization begins, the logic goes, one day the traditions that Carlyle holds dear will eventually come under such scrutiny that they will be forced to justify their existence or "else disappear!" Carlyle believes that the members of this "Aristocracy" are benevolent leaders, and he rightly notices that they are threatened by "rampant" democracy.

In Carlyle's mind, he is making an ethical argument, because he believes that people who lack the autonomy required for democracy must be governed by others. Furthermore, Carlyle argues that those who have the most skill at governing should govern, and those who do not have this skill should not be in the conversation. To put what 
Carlyle calls "the swarm" in control would be, in his mind, against the best interests of "the swarm" itself:

In our own country, too, Swarmery has played a great part for many years past; and especially is now playing, in these very days and months. . . . Ask yourself about "Liberty," for example; what you do really mean by it, what in any just and rational soul is that Divine quality of liberty? That a good man be "free," as we call it, be permitted to unfold himself in works of goodness and nobleness, is surely a blessing to him, immense and indispensable; - to him and to those about him. But that a bad man be "free,"-permitted to unfold himself in his particular way, is contrariwise the fatallest curse you could inflict on him; curse and nothing else, to him and all his neighbours. Him the very Heavens call upon you to persuade, to urge, induce, compel, into something of well-doing; if you absolutely cannot, if he will continue in ill-doing, - then for him (I can assure you, though you will be shocked to hear it), the one "blessing" left is the speediest gallows you can lead him to. ("SN," 8-9)

Carlyle's rhetorical style is verbose, but his point is understood: he opposes democratization because, in his mind, it is not in his nation's best interests. Liberty for the "bad man" is neither good for him nor for his community. Liberty for "bad men"-let alone for women, a proposal that Carlyle does not broach-is in no one's best interests, Carlyle argues, because if suffrage is extended to "bad men," these "bad men," given this liberty, will not only continue to "unfold themselves" in "bad" ways, but after enfranchisement, they will also do bad things with the vote. Who are these "bad men"? What characteristics identify them? Carlyle does not specify, so we are left to assume, as in other areas of his ideal republic, that such judgments are to be left to the "aristocracy." The punishment for being "bad," however, is not in doubt: the "speediest gallows." Carlyle believes he is arguing for his country's best interests - in a manner that is consistent with the long history of political paternalism.

This paternalism is, of course, entirely consistent with racist, classist, and sexist ideologies. Carlyle's skepticism of the autonomy of common people is amplified in his continued comments about "the swarm." "By far the notablest result of Swarmery, in these times," Carlyle argues,

is that of the late American [Civil] War, with Settlement of the Nigger Question for result. Essentially the Nigger Question was one of the smallest; and in itself did not much concern mankind in the present time of struggles and hurries. One always rather likes the Nigger; evidently a poor blockhead with good dispositions, with affections, attachments, - with a turn for Nigger Melodies, and the like: - he is the only Savage of all the coloured races that doesn't die out on sight of the White Man; but can actually live beside him, and work and increase and be merry. The Almighty Maker has appointed him to be a Servant. ("SN," 5) 
For Carlyle, "the swarm" is a term with clear racial implications, but it is also a term that includes a broader swath of people who "attempt to cut asunder [their] straps and fetters":

Certain it is, there is nothing but vulgarity in our People's expectations, resolutions or desires, in this Epoch. It is all a peaceable mouldering or tumbling down from mere rottenness and decay; whether slowly mouldering or rapidly tumbling, there will be nothing found of real or true in the rubbish-heap, but a most true desire of making money easily, and of eating it pleasantly. ("SN" 22)

While Carlyle also has biting comments for "the vulgar millionaire," who he believes to be a "'bloated' specimen" ("SN," 35), Carlyle's racist epithets and his comments about the "Trades Union, in quest of its '4 eights,' with assassin pistol in its hand" ("SN," 35-36) are delivered with far more hostility. These " 4 eights," a reference to the labor movement's demand for "Eight hours to work, eight hours to play, / Eight hours to sleep, and eight shillings a day" ("SN," 35), are indicative of the threats that the swarm makes to the "old order." Carlyle assumes a gender hierarchy, and explicitly argues for racial and class hierarchies, but his vision of a natural and just order is laughable.

Carlyle's counterproposal to stem democratization is to discipline the swarm through military drill:

[O]ne often wishes the entire Population could be thoroughly drilled; into coöperative movement, into individual behaviour, correct, precise, and at once habitual and orderly as mathematics, in all or in very many points, - and ultimately in the point of actual Military Service, should such be required of it! ("SN," 46)

"Discipline," Carlyle argues, is what the swarm needs. This training is "one of the noblest capabilities of man," and it preserves "man's heavenborn Docility" ("SN," 48). But even further, Carlyle argues that such methods would be sources of "pleasure" for the swarm. If we could only learn to accept the orderly habits of mind and body that precise drill teaches, Carlyle argues, we could also learn that following orders and marching in lockstep is somehow pleasurable. This is the flipside of the hierarchical coin: if the problem of politics is finding and training the right leaders, one also needs methods of training the followers to be docile. The backhand side of Carlyle's paternalism is domination disguised as doing "good" works.

To be fair, Carlyle is no determinist: he does not believe that one's position at birth damns one to continuous membership in the "rubbish-heap." Carlyle makes exceptions for those rare cases he calls "heroes"-individuals who can rise above the "swarm" by virtue of their exceptional nature: 
[The] Industrial hero, here and there recognisable and known to me, as developing himself, and as an opulent and dignified kind of man, is already almost an Aristocrat by class. . . . He cannot do better than unite with this naturally noble kind of Aristocrat by title; the Industrial noble and this one are brothers born; called and impelled to coöperate and go together. Their united result is what we want from both. And the Noble of the Future,-if there be any such, as I well discern there must,-will have grown out of both. ("SN," 34-35)

Carlyle expresses the aristocratic wish for enlightened forms of authority: the problem he believes needs solving is to identify and train the people who would most skillfully hold the reins of power, regardless of whether these heroes are industrial workers or bluebloods. Even a representative democracy - which Carlyle tellingly calls an "anarchic Parliament" ("SN," 49) -would go too far in its "Count of Heads" ("SN," 1).

We can place what Betsy Erkkila names "Carlyle's call for an authoritarian state" (254) into an intellectual history, but this history is not past. Carlyle echoes Plato's argument from The Republic about an ideal society where "those who govern must be the best." ${ }^{33}$ As C. L. R. James argues, those who share Carlyle's thoughts have always been hostile to the idea that "every cook can govern." As James writes,

we make a colossal mistake if we believe that [these ideas are] past history. For Plato's best known book, The Republic, is his description of an ideal society to replace the democracy, and it is a perfect example of a totalitarian state, governed by an elite. And what is worse, Plato started and brilliantly expounded a practice which has lasted to this day among intellectuals - a constant speculation about different and possible methods of government, all based on a refusal to accept the fact that the common man can actually govern. (par. 51)

The language Carlyle uses in his argument is different than the language that Plato uses in his, but the goal is hauntingly similar-they favor a restriction of democracy because to reinforce a hierarchy is to keep the "swarm" subordinated to the "aristocracy." The justification that Plato and Carlyle use is consistent: they argue that the effective and efficient administration of any community requires the wisdom and technical skill of an authority. When political movements challenge that authority, the very foundation of the community is called into question. Therefore, race, gender, or class-based hierarchies, in Carlyle's vision, are not problematic; rather, they contribute to the overall stability of the community. If democracy is extended too quickly, too widely, this logic argues, the previously disenfranchised groups actually harm their own interests. If we would only follow the vision of our inspired leaders, Carlyle believes, peace and prosperity would be sure to follow. 


\section{The Democratization of "All Public and Private Life"}

In Whitman's mind, "Shooting Niagara" was a return to the past, a regression to an older, inferior form of politics. Whitman set out to write about things yet to come, to help to enact democracy's future ( $P W$, $2: 392-393)$. He believed that democracy was in its "embryo condition" (PW, 2:392), and, therefore, he "presume [d] to write, as it were, upon things that exist not, and travel by maps yet unmade, and a blank" ( $P W$, $2: 391)$. Because "Whitman worked from the premise that his duty as the national bard was to put democratic theory, the cultural lifeblood of nineteenth-century America, to verse" (Mack, 160), Carlyle's essay must have seemed like an attack on the principles that Whitman had spent most of his life defending. Nevertheless, when Whitman writes about "Shooting Niagara" in Democratic Vistas, he displays an immense capacity to empathize with the arguments that Carlyle makes.

I was at first roused to much anger and abuse by this essay from Mr. Carlyle, so insulting to the theory of America-but happening to think afterwards how I had more than once been in the like mood, during which his essay was evidently cast, and seen persons and things in the same light, (indeed some might say there are signs of the same feeling in these Vistas) - I have since read it again, not only as a study, expressing as it does certain judgments from the highest feudal point of view, but have read it with respect as coming from an earnest soul, and as contributing certain sharp-cutting metallic grains, which, if not gold or silver, may be good hard, honest iron. (PW, 2:375-376)

Whitman recognizes that Carlyle's arguments are not to be hastily dismissed. He wants his readers to know that Carlyle writes from "the highest feudal point of view," and that Carlyle's argument could be laudable, perhaps, if one saw the value in defending what Whitman calls "feudalism." But Whitman also wants his readers to know that his "anger and abuse" abated when he realized that he could sympathize with Carlyle.

Erkkila writes that Democratic Vistas "originated in an effort to 'counterblast' Carlyle's attack," but she points out that "Whitman quickly realized that he shared Carlyle's diagnosis of the diseases of democracy" (247). We may be tempted to think that Whitman is conceding to Carlyle when Whitman writes that he has "seen persons and things in the same light" as Carlyle did, but, like Erkkila, we need to deal in shades of nuance to recognize that Whitman's empathy for Carlyle's argument does not equal agreement with Carlyle's argument. Whitman writes that Carlyle- "the eminent person just mention'd""sneeringly asks whether we expect to elevate and improve a nation's politics by absorbing such morbid collections and qualities therein. The point is a formidable one, and there will doubtless always be numbers of solid and reflective citizens who will never get over it" (PW, 2:379). 
But to Whitman, Carlyle provides the best argument one can make in defending "feudalism." This does not mean that arguments defending "feudalism" are very persuasive to democrats, however. Whitman ultimately points out that, though earnestly written, Carlyle's essay contains "certain sharp-cutting metallic grains, which, if not gold or silver, may be good, hard, honest iron" ( $P W, 2: 376)$. The "if not" is important here- "if not gold or silver" implies that these are the metals that are most precious. Whitman acknowledges the worth of Carlyle's argument, but ultimately, he signals that although iron is a valuable metal, democratic arguments, not "feudal" arguments, set the gold standard.

Whitman quickly confronts Carlyle's criticism of the autonomy of "the unnamed, unknown rank and file." Having analyzed "the full conception of these facts and points, and all that they infer, pro and con-with yet unshaken faith in the elements of the American masses, the composites, of both sexes, and even consider'd as individuals" ( $P W$, $2: 372-373)$ in the opening paragraphs of Democratic Vistas, Whitman defends the autonomy of the common people. While Whitman recognizes that people can be "crude," he does not think that this crudeness is a sufficient basis for their continued disenfranchisement (PW, 2:379). Whitman's comments about idiocracy — which he spells "idiocrasy"most clearly separate Whitman's point of view from Carlyle's. Idiocracy, which literally means personal-rule or government, is a loose synonym for autonomy. Many have missed the connection between idiocracy and autonomy, a connection which is underscored by the reference Whitman makes to "John Stuart Mill's profound essay on Liberty in the future" (PW, 2:362). Whitman is of course referring to Mill's "On Liberty," an essay in which Mill examines the tensions between authority and liberty, ultimately arguing for a dramatically expanded conception of liberty. Whitman, of course, would agree with Mill; Carlyle would not.

One concrete example of Whitman's belief in autonomy is his nascent support for women's equality. Approximately fifty years before women won the right to vote, Whitman expressed his support for the suffrage movement:

Democracy, in silence, biding its time, ponders its own ideals, not of literature and art only - not of men only, but of women. The idea of the women of America, (extricated from this daze, this fossil and unhealthy air which hangs about the word lady,) develop'd, raised to become the robust equals, workers, and, it may be, even practical and political deciders with the men. . . . Then there are mutterings, (we will not now stop to heed them here, but they must be heeded,) of something more revolutionary. The day is coming when the deep questions of woman's entrance amid the arenas of practical life, politics, the suffrage, \&c., will not only be argued all around us, but may be put to decision, and real experiment. (PW, 2:389, 401) 
Whitman may not be a feminist by twenty-first-century standards, but for his time, these comments and others he makes regarding women's suffrage are evidence that, at least along gender lines, he tries to imagine a more inclusive idea of democracy. Simply put, whereas Carlyle argues that the "swarm" does not have the capacity for autonomy required by democracy, and that this lack justifies the need for a hero class, Whitman disagrees, and therefore, he argues for a radical reinterpretation of democracy. One wishes that Whitman had stopped to heed other political topics of the day, like the post-bellum debates about enfranchising the newly emancipated Black population, but we do not find these ideas in Whitman's essay. ${ }^{24}$ For this reason alone, Democratic Vistas may be the "secular bible of democracy," but it is a text about ideas that remain unwritten, and a history that has yet to be enacted.

In response to "Shooting Niagara," Whitman proposed a radical reinterpretation of democracy that would expand it beyond issues of governing and elections. As we know, to be radical is to be concerned with the root or the roots, and as such, Whitman's radicalism has less to do with being outside mainstream political opinion (though many of his ideas certainly are), and has more to do with critiquing the roots of "all public and private life"-the assumptions that sustain such institutions. Whitman's proposal in Democratic Vistas is for the radical democratization of civil society - of literature, churches, schools, and even the armed forces:

Did you, too, $\mathrm{O}$ friend, suppose democracy was only for elections, for politics, and for a party name? I say democracy is only of use there that it may pass on and come to its flower and fruits in manners, in the highest forms of interaction between men, and their beliefs - in religion, literature, colleges, and schools-democracy in all public and private life, and in the army and navy. ( $P W, 2: 389)$

The radicalism of Whitman's proposal is palpable: he wants to democratize even the armed forces, the institutions that one might think would be most hostile to democratic organization. But we would not know the extent of this project by reading The Pragmatic Whitman. Mack abridges the quote after "their beliefs," deleting the institutions that Whitman proposes be brought under democratic control (152). The abridged part of the text is vital to advancing the scholarship on Democratic Vistas. Whitman's radical idea is to democratize "all public and private life," an idea that is far-reaching in its implications, and has not been satisfactorily explored.

To abridge the quote is problematic because Whitman underscores the proposal to democratize even institutions like "the army and the navy." A proposal for the democratization of the armed services is an 
ideal well beyond the vision of the pragmatic tradition, but Whitman chooses this example purposefully, and confronts it directly:

The whole present system of the officering and personnel of the army and navy of these States, and the spirit and letter of their trebly-aristocratic rules and regulations, is a monstrous exotic, a nuisance and revolt, and belong here just as much as orders of nobility, or the Pope's council of cardinals. I say if the present theory of our army and navy is sensible and true, then the rest of America is an unmitigated fraud. ( $P W$ 2:389-390)

Why would Whitman place such an emphasis on democratizing the military? One possible answer is that it is difficult to find a set of organizations that are more rigidly hierarchical, and Whitman wants to present this specific challenge. We also remember that the military is Carlyle's model for the broader society, one where his heroes hold a high rank and where the people march in precise formation. It is no accident, then, that Whitman places such an emphasis on democratizing the armed services: to use his language, they are feudal organizations founded on the idea that authority ought to flow from the top of the hierarchy down. Whitman also looks at schools, churches, and literature and observes that they are all operating on similarly feudal foundations.

The problem Whitman sees is that these foundations are antagonistic to democratic ideals. "The spirit and letter" of the rules that govern the military, like other institutions in American civil society, are "aristocratic," and are therefore "exotic": they are not autochthonic, not rooted in America's grass, but rather are borrowed from a country with "feudal" foundations. Whitman's proposal to democratize "all public and private life" would seem to Carlyle to be unwise, impractical, or impossible, but, again, this is because, in Whitman's opinion, Carlyle writes from "the highest feudal point of view" (PW, 2:375). Carlyle operates with a different frame of reference, one that has been shaped by a civil society and a government that had been built upon a non-democratic foundation. Whitman feels that a democratic frame of reference and a democratic ideology are needed to reinterpret all aspects of American civil society, and that this democratization is a test to America itself: either democracy would take root in "all public and private life" or America would be "an unmitigated fraud" (PW, 2:390).

It is precisely this philosophical approach, this willingness to think beyond what now seems possible, that is most appealing, and, importantly, beyond the vision of the pragmatist tradition. While we might wish that Whitman's project were savvier and more fully developed along racial, gender, and class lines, in Democratic Vistas Whitman does speculate about the specific steps needed for this approach. The first step, Whitman writes, was to lay democratic foundations in guiding 
texts; the second step was to insure for material stability and to build infrastructure; and the third step, which had yet to be taken, was to democratize "all public and private life":

The Third stage, rising out of the previous ones, to make them and all illustrious, I, now, for one, promulge, announcing a native expression-spirit, getting into form, adult, and through mentality, for these States, self-contain'd, different from others, more expansive, more rich and free, to be evidenced by original authors and poets to come, by American personalities, plenty of them, male and female, traversing the States, none excepted-and by native superber tableaux and growths of language, songs, operas, orations, lectures, architecture - and by a sublime and serious Religious Democracy sternly taking command, dissolving the old, sloughing off surfaces, and from its own interior and vital principles, reconstructing, democratizing society. (PW 2:410, emphasis mine)

Several of the assumptions here are overly simplistic-about "general suffrage," equitable infrastructure, and "general employment," all having been accomplished already, all of which are rendered with the universal male pronoun, all imagined within the context of the nation state and its subdivisions - and they display Whitman's prejudices and limitations. But because even the "unnamed, unknown rank and file" $(P W, 2: 377)$ possess the capacity for autonomy, Whitman sees no reason why "all public and private life" should not be brought under democratic control. In a certain sense, Whitman is proposing a type of deconstruction with this project: he is not just critiquing "public and private life" as they are, but he is also critiquing their ideological foundations: those "interior and vital principles" are the theoretical scaffolding for democracy; if those foundations were antithetical to democracy then, like the army and the navy, American democracy would be an "unmitigated fraud." Whitman looks at American civil society and finds that much of it is founded upon a "feudal" ideology, not a democratic ideology:

We see the sons and daughters of the New World, ignorant of its genius, not yet inaugurating the native, the universal, and the near, still importing the distant, the partial, and the dead. We see London, Paris, Italy - not original, superb, as where they belong-but second-hand here, where they do not belong. We see the shreds of Hebrews, Romans, Greeks; but where, on her own soil, do we see, in any faithful, highest, proud expression, America herself? I sometimes question whether she has a corner in her own house. ( $P W, 2: 411)$

A democratic community, in Whitman's mind, cannot remain divided for long between a democratic ideal and a reality of a civil society operating with non-democratic foundations. While it may be interpreted as such, we need not believe that Whitman's idea is limited to a feelgood suggestion that a democratic ethos is sufficient-in other words, that just because citizens vote for representatives every two, four, or 
six years, that it somehow means that other spheres of public life are democratic as well. Quite the contrary, to democratize our institutions would mean an organizational upheaval and a redistribution of power. As Jacques Derrida notes, to follow the term's etymology, "democracy would be precisely this, a force (kratos), a force in the form of a sovereign authority (sovereign, that is kurios or kuros, having the power to decide, to be decisive, to prevail, to have reason over or win out over [avoir raison de] and to give the force of law, kuroo), and thus the power and ipseity of the people (demos)." 25 A grassroots political movement to democratize the workplace or the military would inspire the same fear in the corporate CEOs and the generals that the nineteenth-century political movements put in the hearts of Carlyle's heroes.

Whitman was well aware of the difficulty of this task, and likewise aware of the shockwaves such a proposal would send:

For America, type of progress, and of essential faith in man, above all his errors and wickedness - few suspect how deep, how deep it really strikes. The world evidently supposes, and we have evidently supposed so too, that the States are merely to achieve the equal franchise, an elective government - to inaugurate the respectability of labor, and become a nation of practical operatives, law-abiding, orderly and well off. Yes, those are indeed parts of the task of America; but they not only do not exhaust the progressive conception, but rather arise, teeming with it, as the mediums of deeper, higher progress. Daughter of a physical revolution-mother of the true revolutions, which are of the interior life, and of the arts. (PW, 2:410)

Suffrage alone does not "exhaust the progressive conception," in Whitman's words. This, too, for the seeds of a radical project: voting is not the conclusion of democracy, but is, rather, one of its tools. As Whitman did not, we should not assume that voting rights are the end goals of democracy. For Whitman, democracy was a more expansive ideal, including both "physical" and "true" revolutions. It has no teleological end state, but is, rather, something that is always a negotiation between its past, present, and possible futures.

\section{The Radical Whitman}

At the end of Democratic Vistas, Whitman suggests reading his text as a living document, rather than a vision to be imposed upon his readers. He writes,

Books are to be call'd for, and supplied, on the assumption that the process of reading is not a half-sleep, but, in highest sense, an exercise, a gymnast's struggle; that the reader is to do something for himself, must be on the alert, must himself or herself construct indeed the poem, argument, history, metaphysical essay — the text furnish- 
ing the hints, the clue, the start of the framework. Not the book needs so much to be the complete thing, but the reader of the book does. (PW, 2:424-425)

Much of Whitman's vision should remain in the nineteenth century-for example, the limits of his race, gender, and class analysis, his explicit support for Manifest Destiny, his phrases that have a dark nationalistic overtone, and his tendency to suggest that his ideas have divine originsbut his proposal to democratize "all public and private life" is an idea that merits further investigation. How might we interpret "all public and private life," exactly? Whitman does not specify what he means by "all public and private life," other than mentioning religion, literature, colleges, schools, the army, and the navy, nor does he provide much detail about how we might begin this project. But even if he did, we would not want to import Whitman's vision, unaltered, into the twenty-first century. We can, however, use the text to formulate the questions that might help us to imagine new democratic vistas. How might we break our own straps and fetters? How might a democratic military operate? What would a democratic workplace look like? ${ }^{26}$

Rather than articulating visions for others to follow, the better approach is to think of ways that literary study can help to build the grassroots political movements, the widespread organizations, coalitions, and collectivities that have proven themselves historically to have the credibility and force to articulate and implement political change. In the best moments of Democratic Vistas, Whitman refutes the idea that political progress requires putting into place new forms of authority, but rather requires efforts to enhance freedom and autonomy, ideals that are always tempered by the equally important need to live peacefully with others. This idea is one of many reasons why Democratic Vistas continues to have relevance for us.

Ironically enough, Carlyle offers us ideas to consider as well. Carlyle's criticisms are antecedents to the counterarguments for a project of radical democracy, and he also makes a suggestion about the organization of our political movements. Davis writes that

Swarmery threatens to wrest political control from Britain's "Real-Superiors"- the aristocratic heroes who rise in Carlyle's imagination to stand in the breach against lawlessness and mass-rule - the same barbarians at the gates of [Matthew Arnold's] Culture and Anarchy. True emancipation, Carlyle believed, comes from finding and fulfilling one's place in a social hierarchy and paying honorable allegiance to the cultural elite best suited by birth, training, precedent, and disposition to fulfill humankind's 'instinctive desire of Guidance.' Without that guidance, human society devolves into brutal and beastlike forms of existence, no better than cattle, beavers, and bees. (541) 
For Carlyle, the "swarm" implies that political activists are acting as sub-humans, as animals, and he opposes this imagery to that of his hero. The metaphor of a swarm is an apt one, but while Carlyle gives the term a negative inflection, we need not use it in the same way. Carlyle's distain for and fear of the swarm is telling: in one sense, it is the same reaction that an aristocracy has to any democratic movement. In another sense, however, Carlyle's metaphor provides an indication of the characteristics that are needed in contemporary political movements. The person who looks at insect swarms or large political movements in superficial ways tends to see disorder and chaos-much like Carlyle did-but it is more correct to say that these collectivities are highly organized-just not in a hierarchical way. It turns out that horizontal structures, without strict command and control mechanisms, exhibit very complex organizational behavior. ${ }^{27}$

We are only beginning to understand human organization in terms of complex systems, rather than as simple hierarchies, but the weaknesses of hierarchical organization are apparent: when political movements look more like pyramids than like swarms, they become susceptible to bureaucratization, to an emphasis on their leadership, and are more likely to be dominated by doctrinaire party lines than by the intellectual input of all their participants. The swarm, on the other hand, represents a multiple identity, a hydra-like organization that is strong, uncontrollable, and organized horizontally, rather than hierarchically. It is these swarms, the political movements-not the pragmatic vanguards - that transform our politics and our political ideas. ${ }^{28}$ In every political struggle, whether for the electoral franchise, for civil or human rights, for fair working conditions, and in "physical" and "true" revolutions, history shows that political movements-which of course include intellectual workers-have been the forces that have proven able to achieve material, cultural, and political progress. Our task ought not to be to follow the vision of a more enlightened class of leaders, but rather to build political movements capable of achieving the goals we seek.

To do this, we can stand upon Whitman's shoulders, looking further into those democratic vistas, but ultimately, even the view from the vantage point of those large shoulders will be too limited, so we must seek further vistas. The tension brought to the surface in the debate between Carlyle and Whitman, however-a tension between those who would restrict an already restricted definition of democracy and those who would reinterpret and expand democracy in more radical ways-is very much a part of our politics, as is the tension between the demands of authority and the hopes for ever-expanding ideas and practices of liberty and autonomy. This is a point Whitman recognizes-he writes 
that "while many were supposing things established and completed, really the grandest things always remain" ( $P W, 2: 425)$.

The parameters of the debate between Carlyle and Whitman are instructive, and we can continue by revising the questions that Whitman raised and the vistas he imagined. If the democratization of the workplace, the military, or of our schools were put to a real test, the Carlyles of our historical moment will certainly howl much like the nineteenthcentury version did, and this will be one indication that we have begun cutting our own straps and fetters. Once framed in this manner, the ambiguities, nuances, and contingencies of the argument multiply, and complex decisions follow. The "great question[s] of democracy" ( $P W$, $2: 363$ ) have to be addressed from many perspectives, and in specific local and historical contexts, and by credible and powerful political movements. These will be grand and difficult questions, and as such, they can motivate our further research.

\section{State University of New York, Binghamton}

\section{NOTES}

1 Walt Whitman, Prose Works 1892, ed. Floyd Stovall (New York: New York University Press, 1964), 2:393. Hereafter $P W$.

2 Manning Marable, Living Black History: How Reimagining the African-American Past Can Remake America's Racial Future (New York: Basic Civitas Books, 2006), 37.

3 Roberto Mangabeira Unger and Cornel West, The Future of American Progressivism: An Initiative for Political and Economic Reform (Boston: Beacon, 1998), 11.

4 Stephen John Mack, The Pragmatic Whitman: Reimagining American Democracy (Iowa City: University of Iowa Press, 2002), 137.

5 Thomas Carlyle, "Shooting Niagara: And After?" (London: Chapman and Hall, 1867). Hereafter "SN."

6 Thomas Carlyle, On Heroes, Hero-Worship, and the Heroic in History (New York: John Wiley, 1849).

7 Kenneth M. Price, “'Be radical—be radical—be not too damned radical!': The Origins and Resonance of Whitman's Signature Expression," Walt Whitman Quarterly Review 22 (Fall 2004/Spring 2005), 126-129.

8 Michel Fabre, "Walt Whitman and the Rebel Poets: A Note on Whitman's Reputation Among Radical Writers During the Depression," Walt Whitman Review 12 (December 1966), 88-93.

9 George Will, "Iraqi Democratic Vistas.” September 7, 2003. <http://townhall. com/columnists/GeorgeWill/2003/09/07/iraqi_democratic_vistas >.

10 Cornel West, The American Evasion of Philosophy: A Genealogy of Pragmatism (Madison: The University of Wisconsin Press, 1989), 5. 
11 Robert Leigh Davis, "Democratic Vistas" in Donald D. Kummings, ed., A Companion to Walt Whitman (Malden, MA: Blackwell Publishing, 2006), 551.

12 See Ed Folsom, "Lucifer and Ethopia: Whitman, Race, and Poetics before the Civil War and After" in David S. Reynolds, ed., A Historical Guide to Walt Whitman (New York: Oxford University Press, 2000), 45-95.

13 See Santa Clara County v. Southern Pacific R. Co., 118 U.S. 394 (1886). In a statement during the Supreme Court proceedings, Chief Justice Morrison R. Waite stated that the Court did not wish to hear arguments about whether corporations can claim rights as persons under the Fourteenth Amendment, further stating that all members of the court believed that such rights could be claimed. The statement is included in the syllabus for the decision, but not in the opinion of the court. The legal fiction of corporate personhood has recently been concretized by the Supreme Court in Citizens United v. Federal Election Commission, 558 US (2010).

14 The same could be said in this context of Henry David Thoreau's text "Civil Disobedience," which many activists have called upon since the text's publication. Thoreau's comment about corporate morality now seems hopelessly naïve: "[i]t is truly enough said, that a corporation has no conscience; but a corporation of conscientious men is a corporation with a conscience" (2). This is another reason why the task of those who take inspiration or instruction from Thoreau or Whitman is not to use their texts as blueprints to follow, but rather as tools to be used for particular, historically situated purposes. See Henry David Thoreau, "Civil Disobedience," Civil Disobedience and Other Essays (Mineola, NY: Dover, 1993).

15 Walt Whitman, Leaves of Grass: Comprehensive Reader's Edition, ed. Harold W. Blodgett and Sculley Bradley (New York: New York University Press, 1965), 84.

16 David Scott, Conscripts of Modernity: The Tragedy of Colonial Enlightenment (Durham: Duke University Press, 2004), 1.

17 Walt Whitman, The fournalism, Volume II: 1846-48, eds. Herbert Bergman, Douglas A. Noverr, Edward J. Recchia, (New York: Peter Lang, 2003), 89.

18 Thomas F. Haddox, "Whitman's End of History: 'As I Sat Alone By Blue Ontario's Shore,' Democratic Vistas, and the Postbellum Politics of Nostalgia" Walt Whitman Quarterly Review 22 (Summer 2004), 11. In addition to the texts considered in this essay, see, for example, the treatment that the Carlyle/Whitman debate is given in Gregory Paine, "The Literary Relations of Whitman and Carlyle with Especial Reference to Their Contrasting Views on Democracy," Studies in Philology 36 (July 1939), 550-563; David Brooks, "What Whitman Knew," The Atlantic Monthly, 291 (May 2003), 32-33; Robert Weisbuch, Atlantic Double-Cross: American Literature and British Influence in the Age of Emerson (Chicago: University of Chicago Press, 1986); Edward F. Grier, "Walt Whitman, the Galaxy, and Democratic Vistas," American Literature, 23 (November 1951), 332-350; and Robert J. Scholnick, "CCulture' or Democracy: Whitman, Eugene Benson, and The Galaxy," Walt Whitman Quarterly Review 13 (Summer 1996), 189-209.

19 C. L. R. James, "Every Cook Can Govern: A Study of Democracy in Ancient Greece and Its Meaning for Today" < http://www.marxists.org/archive/james-clr/ works/1956/06/every-cook.htm>. 
20 The full version of "Shooting Niagara" was republished in microform by the Lost Cause Press of Louisville, Kentucky, in 1974. Abridged versions of Carlyle's text can be found in several places, including in William E. Buckler, ed., Prose of the Victorian Period (Boston: Houghton, 1958), from which Mack cites. A digital version of the full text, which was used for this essay, can now be found with a Google Books search.

21 James Anthony Froude, Thomas Carlyle: A History of His Life in London, 1834-1881, vol. II (New York: Charles Scribner's Sons, 1898), 300.

22 See Betsy Erkkila, Whitman the Political Poet (New York: Oxford University Press, 1989), 247. For an additional discussion of the British Reform Acts, see Eric J. Evans, Parliamentary Reform in Britain, c. 1770-1918 (New York: Longman, 2000).

23 Plato, The Republic (London: Penguin, 2003), 412c.

24 See Luke Mancuso, The Strange Sad War Revolving: Walt Whitman, Reconstruction, and the Emergence of Black Citizenship, 1865-1876 (Columbia, SC: Camden House, 1997), especially Chapter Two, “'Reconstruction is still in abeyance': Walt Whitman's Democratic Vistas and the Federalizing of National Identity."

25 Jacques Derrida, Rogues: Two Essays on Reason (Stanford: Stanford University Press, 2005), 13.

26 There are examples to be studied, of course. George Orwell serves in a democratic army during the Spanish Civil War, an experience he describes in Homage to Catalonia (Orlando: Harvest, 1980). In the wake of Argentina's 2001 financial crisis, approximately 200 shuttered workplaces have been reopened by their former workers and have been reorganized along democratic lines in a process these workers call "recuperation." See Marie Trigona, "Recuperated Enterprises in Argentina: Reversing the Logic of Capitalism" in Citizen Action in the Americas 19 (March 2006), 1-8. For a good history of these ideas in the United States, see David Montgomery, Workers' Control in America: Studies in the History of Work, Technology, and Labor Struggles (Cambridge: Cambridge University Press, 1992).

27 For information on the study of complex systems like swarms, crowds, and other non-hierarchical forms of organization, see Manuel DeLanda, A New Philosophy of Society: Assemblage Theory and Social Complexity (London: Continuum, 2006); Steven Johnson, Emergence: The Connected Lives of Ants, Brains, Cities, and Software (New York: Scribner, 2001); and Melanie Mitchell, Complexity: A Guided Tour (New York: Oxford University Press, 2009).

28 Peter Linebaugh and Marcus Rediker provide a sweepingly persuasive argument for reading historical struggles in just this way in The Many-Headed Hydra: Sailors, Slaves, Commoners, and the Hidden History of the Revolutionary Atlantic (Boston: Beacon, 2000). 